\title{
PERSPEKTIF HUKUM DAN KEADILAN TERHADAP KASUS BUAH RANDU DI KABUPATEN BATANG
}

\author{
Waidin \\ Fakultas Hukum Universitas Jenderal Soedirman Purwokerto, Jawa Tengah
}

\begin{abstract}
Human needs society to socialize and to maintain the orderliness in the society required norms as guidelines. One of these norms is legal norm that not only written law but also an unwritten law such as customary law and customs of society. The main purpose of law is justice, because it can maintain relationship with the community. Therefore, law enforcement officer carrying out their duties to make justice, not merely apply the law texts for the sake of legal certainty. In the case of cotton fruits, judges prefer to the certainty of the law rather than justice. The judge did not consider the habits of the local community, that's why the perpetrator felt unfairly treated. To create justice in the society, judges should not only guide by the law text but must also consider the habits of the local community.
\end{abstract}

Keyword: Law, justice and legal certainty

\begin{abstract}
Abstrak
Manusia memerlukan masyarakat untuk bersosialisasi dan untuk memelihara ketertiban dalam masyarakat diperlukan pedoman berupa norma. Salah satu norma yang berlaku adalah norma hukum yang sifatnya bukan hanya tertulis namun juga tidak tertulis seperti hukum adat dan kebiasaan dalam masayarakat. Tujuan dari hukum adalah keadilan karena digunakan untuk memelihara hubungan antarmasyarakat. Oleh karena itu, aparat penegak hukum harus berientasi pada penciptaan keadilan, tidak hanya pada aspek kepastian hukum. Dalam kasus buah randu ini, hakim cenderung kepada kepastian hukum dibandingkan dengan keadilan. Hakim tidak mempertimbangkan kebiasaan dalam yang berlaku dalam masyarakat lokal, oleh karenanya para pelanggar merasa keadilannya terbelenggu. Untuk menciptakan keadilan dalam masyarakat, seharusnya hakim tidak hanya dipandu oleh hukum tetulis namun juga harus mempertimbangkan kebiasaan yang berlaku dalam masyarakat lokal.
\end{abstract}

Kata kunci: hukum, keadilan dan kepastian hukum.

\section{Pendahuluan}

Buah Randu Memburamkan Masa Depan Sri Suratmi. Demikian bunyi judul sebuah artikel yang ditulis oleh seorang Herpin Dewanto pada harian Kompas terbitan hari Kamis tanggal 28 Januari 2010. Isi tulisan tersebut menyoroti bahwa nasib Sri Suratni (19) yang oleh jaksa penuntut umum dituntut satu bulan penjara dengan masa percobaan dua bulan pada hari Selasa tanggal 26 Januari 2010 pada sidang Pengadilan Negeri Batang karena terdakwa telah mencuri buah Randu total seberat $14 \mathrm{~kg}$ di areal Perkebunan PT Sugayang di Desa Sumbojo, Kecamatan Tulio Kabupaten Batang.
Kasus ini berawal dari perbuatan Sri Suratni (19), Manisih (40), anak kandung Manisih, Juwono (16) dan Rustono (14) yang memungut Randu di areal Perkebunan PT Sugayang di Desa Sumbojo, Kecamatan Tulio Kabupaten Batang pada tanggal 2 November 2009. Mereka tidak menyangka kalau perbuatannya berbuntut panjang sampai berurusan dengan aparat penegak hukum.

Bagi Sri Suratmi dan kawan-kawan, apa yang dilakukannya adalah hal biasa karena pengambilan Randu yang sudah dipanen oleh pemiliknya, jadi sudah merupakan sisa, bukan merupakan perbuatan yang melanggar hukum, 
bukan dianggap sebagai pencurian. Sudah menjadi kebiasaan masyarakat setempat bahwa setelah Randu dipanen oleh pemiliknya, mereka akan mengambil sisa-sisa randu setelah panen.

Menurut Kepala Desa Kenconorejo, Nur Ajidah, selama ini tidak pernah terjadi warga yang "nggresek" diperkebunan randu harus berakhir di Pengadilan. Pasalnya kegiatan itu sudah menjadi tradisi ssebagian besar warga di desa itu untuk mencari uang. Mereka mengambil sisa-sisa panen randu untuk dijual. ${ }^{1}$

Lain halnya bagi para penegak hukum, yang bagaimanapun mereka harus berpegang pada hukum positif tertulis yang berlaku. Berdasarkan KUHP, pengambilan Randu yang merupakan milik orang lain untuk dimiliki sendiri tanpa persetujuan pemiliknya adalah pencurian. Dalam rangka menegakan hukum maka pengambilan Randu yang demikian itu harus ditindak.

Kasus yang menimpa Sri Suratni dan kawan-kawan akhirnya membawa mereka sampai pada proses sidang di Pengadilan dan dijatuhi hukuman pidana penjara selama 24 hari. Hal inilah yang menimbulkan pertanyaan : Adilkah memperlakukan Sri Suratni dan kawan-kawan sebagai pelaku pencurian dan harus menjalani hukuman penjara selama 24 hari?

\section{Pembahasan}

\section{Pengertian Kepastian}

Manusia adalah mahluk sosial. Sebagai mahluk sosial, dalam hidupnya manusia membutuhkan manusia lainnya untuk berinteraksi satu sama lain. Dalam berinteraksi dengan manusia lain inilah mereka dapat mengekpresikan dirinya sebagai mahluk yang memiliki cita, rasa dan karsa, sehingga kita tidak mungkin menggambarkan hidupnya manusia tanpa atau di luar masyarakat. ${ }^{2}$

Untuk mempertahankan keberadaan masyarakat ini maka dalam kehidupan bersama itu perlu diciptakan suasana yang tertib atau dengan kata lain diperlukan ketertiban. Jadi kebutuhan

Amanda Putri, Ketika "Nggresek" Membawa Petaka, Harian Kompas, Rabu, 3 Febuari 2010, hlm.1

Mochtar Kusumaatmadja, 2002, Konsep-konsep Hukum Dalam Pembangunan, Bandung: Alumni, hlm. 3 akan ketertiban merupakan syarat pokok (fundamental) bagi adanya suatu masyarakat manusia yang teratur. ${ }^{3}$ Untuk mencapai ketertiban dalam masyarakat maka diperlukan adanya kepastian dalam pergaulan antar manusia dalam masyarakat. Dalam rangka menjamin kepastian ini maka dalam masyarakat diperlukan adanya norma-norma sebagai pedoman dalam bertindak. Dengan adanya normanorma ini masyarakat dapat memprediksikan apa yang akan terjadi bila melakukan perbuatan tertentu. Salah satu norma yang terdapat dalam pergaulan antar manusia adalah norma hukum.

Hukum memang berbicara dan berurusan dengan ketertiban. Hukum menempatkan diri sebagai penjaga, pengatur dan produsen penertiban. Oleh karena itu dia tampil dengan membuat macam-macam peraturan, seruan dan larangan, hukum menjadi institusi normatif. ${ }^{4}$ Hal ini tercermin dari definisi hukum yang mengatakan bahwa hukum adalah aturanaturan tingkah laku manusia yang berisi larangan, keharusan,dan kebolehan atau anjuran yang mempunyai sanksi yang dapat dipaksakan bagi anggota yang melanggar aturanaturan tersebut. ${ }^{5}$

Sehubungan dengan definisi tersebut, menurut Iswanto, aturan-aturan yang dimaksud meliputi aturan yang tertulis yang disebut peraturan dan yang tidak tertulis yang disebut adat kebiasaan yang diakui keberlakuannya. ${ }^{6}$ Dengan demikian maka di dalam masyarakat, disamping berlaku hukum yang tertulis yang berbentuk peraturan, berlaku juga hukum tidak tertulis yang disebut adat kebiasaan.

Menurut Satjipto Rahardjo, hukum tidak ada untuk diri dan keperluannya sendiri, melainkan untuk manusia, khususnya kebahagiaan manusia. Jadi berdasarkan pendapat tersebut maka keberadaan hukum adalah untuk kepentingan manusia, dalam hal ini adalah kepentingan manusia dalam berhubungan dengan

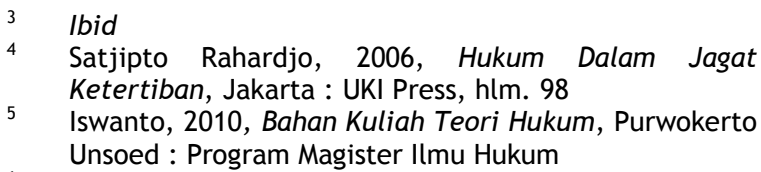


manusia yang lain atau dengan kata lain hukum adalah untuk kepentingan masyarakat.

Menurut Satjipto Rahardjo, masyarakat tidak hanya ingin melihat keadilan diciptakan oleh hukum dan kepentingan-kepentingannya dilayani oleh hukum, melainkan mereka juga menginginkan agar dalam masyarakat terdapat peraturan-peraturan yang menjamin kepastian dalam hubungan mereka satu sama lain. Dengan demikian, hukum itu dituntut untuk memenuhi berbagai karya yang oleh Gustaf Radbruch disebut sebagai tiga nilai-nilai dasar dari hukum. Ketiga nilai dasar tersebut meliputi nilai dasar Keadilan, nilai dasar Kegunaan atau Manfaat dan nilai dasar Kepastian. Ketiga nilai dasar ini mempunyai dasar keabsahannya sendiri-sendiri. Nilai dasar Keadilan, keabsahan berlakunya adalah secara filosofis. Nilai dasar Kegunaan keabsahan berlakunya adalah secara sosiologis dan Nilai dasar Kepastian keabsahan berlakunya adalah secara yuridis. ${ }^{7}$

Sekalipun ketiganya merupakan nilai dasar hukum, namun diantara mereka dapat terjadi saling ketegangan satu sama lain. Ketegangan itu bisa dimengerti oleh karena ketiga-tiganya berisi tuntutan yang berlain-lainan yang satu sama lain mengandung potensi untuk bertentangan. ${ }^{8}$ Apabila diambil sebagai contoh kepastian hukum maka sebagai nilai ia segera menggeser nilainilai keadilan dan kegunaan kesamping. Menurut Radbruch, jika terjadi ketegangan antara nikainilai dasar tersebut, kita harus menggunakan dasar atau asas prioritas dimana prioritas pertama selalu jatuh pada nilai keadilan, baru nilai kegunaan atau kemanfaatan dan terakhir kepastian hukum. ${ }^{9}$ Ini menunjukan bahwa Radbruch menempatkan nilai keadilan lebih utama dari pada nilai kemanfaatan dan nilai kepastian hukum dan menempatkan nilai kepastian hukum di bawah nilai kemanfaatan.

Pendapat berbeda dikemukakan oleh Achmad Ali, yang menyatakan bahwa ia sendiri setuju dengan asas prioritas tetapi tidak dengan

Satjipto Rahardjo, 2000, Ilmu Hukum, Bandung: Citra Aditya Bakti, hlm.19

8 Loc.Cit

$9 \quad$ Ahmad Ali , 1996, Menguak Tabir Hukum (Suatu Kajian Filosofis dan Sosiologis), Jakarta: Chandra Pratama, hlm. 96 menetapkan urutan prioritas sebagaimana dikemukakan oleh Radbruch. la menganggap merupakan hal yang lebih realistis jika kita menganut asas prioritas yang kasuistis.Yang ia maksudkan ketiga nilai dasar hukum diprioritaskan sesuai kasus yang dihadapi. Menurutnya jika asas prioritas kasuistis ini yang dianut maka sistem hukum kita akan terhindar dari berbagai konflik yang tidak terpecahkan. ${ }^{10}$

Di atas disebutkan bahwa antara nilainilai dasar hukum dapat terjadi ketegangn. Ketegangan ini muncul pada saat hukum tersebut diterapkan dalam proses persidangan di Pengadilan. Hal ini terjadi karena dalam proses penerapan hukum di Pengadilan terdapat faktor yang mempengaruhi para penegak hukum, di antaranya adalah norma yang berlaku bagi mereka yang ditetapkan oleh pembuat undangundang.dan kekuatan sosial dan pribadi.

Menurut Chambliss \& Seidman, sebagaimana dikutip oleh Satjipto Rahardjo bahwa dalam membuat hukum lembaga pembuat hukum dipengaruhi oleh semua kekuatan sosial dan pribadi. Norma-norma yang dibuat oleh lembaga pembuat hukum ini disamping ditujukan kepada rakyat, juga ada norma yang ditujukan kepada lembaga-lembaga penerap sanksi. Ini berarti bahwa dalam fungsinya sebagai lembaga penerap sanksi, dalam melaksanakan tugasnya ia terikat oleh norma yang berasal dari lembaga pembuat hukum. Disamping itu ia juga dipengaruhi oleh semua kekuatan sosial dan pribadi.

Disamping pengaruh dari faktor-faktor tersebut di atas, lembaga penerap sanksi juga dipengaruhi oleh teori hukum yang dianutnya. Menurut Algra dan van Duyvendijk, sebagaimana dikutip oleh H.Pontang Moerad B.M, ${ }^{11}$ dalam memutus suatu perkara, ajaran hukum alam mengutamakan keadilan, sedangkan positivisme hukum mengutamakan penemuan hukum dan kepastian hukum. Dengan demikiam maka bila seorang hakim menganut ajaran atau teori hukum alam, ia akan mengutamakan

\footnotetext{
Ibid

H.Pontang Moerad B.M, 2005, Pembentukan Hukum Melalui Putusan Pengadilan Dalam Perkara Pidana, Bandung: Alumni, hlm.21
} 
keadilan dan bagi hakim yang menganut positivisme akan mengedepankan kepastian hukum, ia akan berpegang teguh pada bunyi teks undang-undang, seperti para hakim dinegara-negara yang termasuk dalam keluarga sistem hukum civil law dimana undang-undang dijadikan pedoman dalam memutus perkara di persidangan.

\section{Pengertian Keadilan}

Hukum tidak ada untuk diri dan keperluannya sendiri melainkan untuk manusia, khususnya kebahagiaan manusia. ${ }^{12}$ Hukum tidak memiliki tujuan dalam dirinya sendiri. Hukum adalah alat untuk menegakkan keadilan dan menciptakan kesejah-terahan sosial. ${ }^{13}$ Tanpa keadilan sebagai tujuan ultimumnya, hukum akan terperosok menjadi alat pembenar kesewenang-wenangan mayoritas atau pihak penguasa terhadap minoritas atau pihak yang dikuasai. Itulah sebabnya maka fungsi utama dari hukum pada akhirnya menegakkan keadilan. ${ }^{14}$

Pertanyaannya adalah "Apa itu keadilan"? Pertanyaan seputar apa itu "keadilan" adalah sebuah pertanyaan yang acap kali kita dengar, namun pemahaman yang tepat justru rumit dan abstrak, terlebih bila dikaitkan dengan berbagai kepentingan yang kompek. ${ }^{15}$ Oleh karena itu banyak pakar yang mengemukan pendapat tentang keadilan ini. Keadilan adalah suatu konsep yang relevan dengan hubungan antar manusia, dan karena itu dia harus dibahas dalam kontek yang sosial sifatnya. ${ }^{16}$

Dalam bukunya yang berjudul "Nichomachean ethik", Aristoteles mengatakan keadilan artinya berbuat kebajikan atau dengan kata lain keadilan adalah kebajikan yang utama. Menurut Aristoteles, "justice consist in treating equals equally and unequal unequally, in proportion to their inequallity". Prinsip ini beranjak dari

12 Satjipto Rahardjo, 2007, Biarkan Hukum Mengalir, Jakarta: Kompas, hlm. IX

13 Andre Ata Ujan, 2009, Filsafat Hukum, Yogyakarta: Kanisius, hlm. 12

14 Budiono Kusumohamidjojo, 1999, Ketertiban Yang Adil, Jakarta: Grasindo , hlm.126

15 Agus Yudha Hernoko, 2008, Hukum Perjanjian, Asas Proposionalitas Dalam Kontrak Komunersial, Yogyakarta: Laks Bang Mediatama, hlm. 35

16 Kusumohamidjojo, Op.Cit, hlm. 113 asumsi untuk hal-hal yang sama diperlakukan secara sama,dan yang tidak sama juga diperlakukan tidak sama, secara proporsional. ${ }^{17}$ Ulpianus $^{18}$ menggambarkan keadilan sebagai "justitia est constan et perpetua voluntas ius suum cuique tribuendi" (keadilan adalah kehendak yang terus menerus dan tetap memberikan kepada masing-masing apa yang menjadi haknya.) atau "tribuere cuique suum""to give everybody his own". Memberikan kepada setiap orang apa yang menjadi haknya. ${ }^{19}$ Perumusan ini dengan tegas mengakui hak masing-masing person terhadap lainnya serta apa yang menjadi bagiannya, demikian pula sebaliknya. Pengertian ini diambil alih oleh Justinianus dalam Corpus iuris civilis. Juris praecepta sunt haec: honesty vivere, alterum non laedere, suum cuique tribuere, bahwa peraturan-peraturan dasar dari hukum adalah terkait hidup dengan patut, tak merugikan orang lain dan memberi kepada orang lain apa yang menjadi bagiannya. ${ }^{20}$

Menurut Cicero, keadilan adalah keutamaan moral paling utama atau "mahkota" kemuliaan semua keutamaan moral. Keadilan adalah prinsip yang memungkinkan masyarakat dan ikatan bersama dipertahankan. Ketidakadilan merupakan hal yang fatal bagi kehidupan sosial dan persahabatan manusia dengan manusia. ${ }^{21}$ Itulah sebabnya maka.tujuan pertama dan utama keadilan adalah menjaga agar seseorang tidak merugikan orang lain, kecuali jika orang lain itu telah melakukan kesalahan. ${ }^{22}$

Menurut Sonny Keraf secara tradisional dikenal ada tiga macam bentuk keadilan. Ketiga bentuk keadilan Yaitu Pertama, Keadilan legal. Keadilan legal menyangkut hubungan antara individu atau kelompok masyarakat dengan negara. Intinya adalah semua orang atau kelompok masyarakat diperlakukan secara sama oleh negara di hadapan dan berdasarkan hukum yang berlaku. Semua pihak dijamin untuk men-

Agus Yudha Hernoko , Op Cit, hlm. 36

Ibid

K Berten, 2000, Pengantar Etika Bisnis, Yogyakarta: Kanisius, hlm. 86-87

20 Agus Yudha Hernoko, Op Cit, hlm. 36

21 Sonny Keraf, 1997, Hukum Kodrat Dan Teori Hak Milik Pribadi, Yogyakarta: Kanesius, hlm.17

22 Ibid 
dapat perlakuan yang sama sesuai dengan hukum yang berlaku.Kedua, Keadilan komutatif. Keadilan ini mengatur hubungan yang adil atau fair antara orang yang satu dan yang lain atau antara warga negara yang satu dan warga negara lainnya. Dengan kata lain, kalau keadilan legal lebih menyangkut hubungan vertikal antara negara dan warga negara, keadilan komutatif menyangkut hubungan horizontal antara warga yang satu dan warga yang lain. Ketiga, Keadilan distribusi. Prinsip dasar keadilan distributif, atau yang kini dikenal sebagai ekonomi, adalah distribusi ekonomi yang merata atau yang dianggap adil bagi semua warga negara. Dengan kata lain, keadilan distributif menyangkut pembagian kekayaan ekonomi atau hasil-hasil pembangunan. ${ }^{23}$

Selain ketiga bentuk keadilan tersebut, terdapat beberapa bentuk yang lain. John Boatright dan Manuel Velasquez mengemukakan tiga bentuk keadilan, yaitu Pertama, Keadilan Distributif (distributive justice), mempunyai pola tradisional, dimana benefits and burdens harus dibagi secara adil. Kedua, Keadilan Retributive (retributive justice), berkaiatan dengan terjadinya kesalahan, dimana hukum atau denda dibebankan kepada orang yang bersalah harulah bersifat adil. Ketiga, Keadilan kompensatoris (compensatory justice), menyangkut juga kesalahan yang dilakukan, tetapi menurut aspek lain, dimana orang mempunyai kewajiban untuk memberikan kompensasi atau ganti rugi kepada pihak lain yang dirugikan. ${ }^{24}$

Berdasarkan uraian tersebut maka dapat diketahui bahwa inti keadilan adalah supaya orang tidak dirugikan, kecuali orang itu bersalah atau merugikan orang lain. Adapun bentuk bentuk keadilan ini bermacam-macam, ada yang mengatakan orang harus menerima haknya, adapula yang mengatakan orang harus diperlakukan sama di depan hukum, dan adapula yang mengatakan bahwa orang harus menerima keuntungan dan beban yang sama. Bentuk-bentuk keadilan ini adalah perwujudan dari inti keadilan

23 Sonny Keraf, 1998, Etika Bisnis, Yogyakarta: Kanisius, hlm. 138-143

24 Manuel G Velasques, 2005, Etika Bisnis, Konsep dan Kasus, Yogyakarta: Andi, hlm. 111-114 dalam kaitannya dengan berbagai macam bentuk hubungan yang terjadi dalam masyarakat.

\section{Keadilan Dalam Kasus Randu}

Mengingat fungsi utama dari hukum pada akhirnya adalah menegakkan keadilan dan hukum tidak hanya berupa undang-undang melainkan juga hukum kebiasaan masyarakat setempat yang tidak tertulis ${ }^{25}$ maka dalam melaksanakan tugasnya sebagai penegak hukum, pihak kepolisian, kejaksaan, dan pengadilan tidak hanya menegakkan bunyi teks yang tercantum dalam kitab undang-undang, tetapi harus memperhatikan kebiasaan dan adat istiadat masyarakat setempat.

Dikaitkan dengan kasus buah randu yang melibatkan Sri Suratmi dan kawan-kawan yang oleh pihak kejaksaan didakwa sebagai pencuri dan oleh jaksa pada tannggal 26 Januari 2010 dituntut hukuman penjara sebulan penjara dengan masa percobaan empat bulan dan pada hari Selasa tanggal 2 Februari 2010 oleh majelis hakim yang diketuai oleh Tirolian Nainggolan dalam sidang di Pengadilan Negeri Batang, dinyatakan bersalah dan dijatuhi hukuman penjara selama 24 hari, maka tampaklah bahwa para penegak hukum yang menangani kasus buah randu ini yaitu pihak kepolisian dan pihak kejaksaan, dan hakim yang menadili kasus tersebut hanya berpedoman pada bunyi teks yang tercantum dalam KUHP, khususnya pasal yang mengatur tentang pencurian, yaitu pasal 363 ayat (1) ke 4 KUHP. Kejadian semacam ini tidak aneh mengingat bahwa sistem hukum Indonesia menganut sistem hukum civil law. Dalam negara yang sistem hukumnya termasuk dalam sistem hukum civil law maka dalam proses penegakkan hukumnya, para penegak hukum sangat berpegang teguh pada undangundang. Mereka melihat teks yang tercantum dalam kitab undang-undang bersifat otonom, teks tersebut tidak terpengaruh oleh faktorfaktor non hukum seperti keadilan dan kebiasaan setempat. Dengan pandangan yang demikian, maka dalam menegakkan hukum mereka hanya melihat apakah suatu perbuatan

25 Soetandyo Wignjosoebroto, 2008, Hukum Dalam Masyarakat, Surabaya: Bayumedia Publishing, hlm. 35 
itu sudah memenuhi rumusan delik atau tidak. Jika sudah memenuhi rumusan delik maka perbuatan itu dianggap sebagai perbuatan yang melawan hukum yang harus ditindak. Demikian juga yang terjadi pada diri Sri Suratmi dan kawan-kawan. Ketika mereka mengambil buah randu milik orang lain untuk dimiliki sendiri tanpa seijin pemiliknya maka perbuatan mereka diklasifikan sebagai pencurian, yang kemudian perbuatan tersebut membawa mereka berurusan dengan pihak kepolisian dan kejaksaan yang akhirnya sampai ke proses persidangan dalam pengadilan, dimana dalam persidangan tersebut jaksa menuntut hukuman satu bulan penjara dengan masa percobaan empat bulan dan oleh mejelis hakim akhirnya mereka dijatuhi hukum penjara selama 24 hari.

Dilihat dari sudut pandang teori dari Chamblis \& Seidman, maka para penerap sanksi hanya melihat pada norma hukum yang ditujukan kepada warga dan norma yang ditujukan kepada mereka. Para penegak hukum itu tidak memperhatikan kebiasaan dalam masyarakat. Dilihat dari sudut pandang teori dalam memutus perkara sebagaimana dikemukakan oleh N.E Algra dan K.van Duyvendijk, maka para penegak hukum itu mendasarkan pada teori Positivisme hukum sehingga yang diutamakan dalam memutus perkara adalah kepastian hukum. Mereka telah mengabaikan keadilan yang dituntut oleh para terpidana yang merasa telah dirugikan dengan dijatuhkannya pidana penjara selama 24 hari. Para terpidana merasa bahwa mereka tidak melakukan pencurian yang dituduhkan oleh jaksa karena apa yang mereka lakukan adalah pengambilan barang sisa yang mereka anggap, juga bagi warga setempat, tidak lagi diperlukan oleh pemiliknya.

Akan lain ceritanya jika para penegak hukum itu dalam menjalankan hukum tidak hanya didasarkan logika peraturan, tetapi juga logika lain seperti keadilan dan kenyataan sosial. ${ }^{26}$ Apa yang oleh pihak kepolisian, kejaksaan dan majelis hakim dianggap sebagai pencurian, ternyata oleh masyarakat setempat tidak dianggap sebagai pencurian. Pengambilan

26 Satjipto Rahardjo, 2006, Membedah Hukum Progresif, Jakarta : Kompas, hlm. 65 randu sisa setelah dipanen oleh pemiliknya bagi masyarakat setempat bukan pencurian yang berarti bahwa yang mengambil itu bukan pencuri. Dalam kasus ini telah terjadi ketegangan antara nilai dasar kepastian hukum yang dipegang teguh oleh para penegak hukum dengan nilai dasar keadilan hukum yang didambakan oleh para terpidana dan masyarakat setempat. Hal ini terlihat dari sikap para pengunjung sidang yang mendukung terpidana. Berdasarkan keadilan legal dimana semua pihak dijamin untuk mendapat perlakuan yang sama sesuai dengan hukum yang berlaku maka apa yang menimpa Sri Suratmi dan kawan-kawan jelas tidak adil karena mereka telah diperlakukan sebagai pencuri padahal mereka merasa tidak pernah mencuri yang berarti juga para terpidana ini merasa tidak pernah merugikan pemilik randu. Jika para terpidana ini harus menjalani hukuman penjara maka mereka telah dirugikan yang berarti juga mereka telah diperlakukan tidak adil.

\section{Penutup \\ Simpulan}

Penegakan hukum yang hanya berpedoman pada teks yang dirumuskan dalam kitab undang-undang tanpa mempertimbangkan kebiasaan masyarakat dapat menimbulkan ketidakadilan di hati masyarakat. Begitu juga dengan putusan majelis hakim yang hanya mendasarkan diri pada teori posivisme, yang hanya memperhatikan pada kepastian hukum tanpa mempertimbangkan teori hukum alam yang mengutamakan keadilan hukum, dapat menimbukan ketidak adilan dalam masyarakat.

\section{Saran}

Penegak hukum dalam melaksanakan tugasnya jangan hanya berpedoman pada teks yang tercantum dalam Undang-Undang saja tetapi juga harus memperhatikan kebiasaan dan rasa keadilan masyarakat. Mereka jangan hanya berpegang pada teori positivisme dalam menangani suatu kasus, tetapi juga harus mempertimbangkan teori hukum alam yang sangat menjunjung tinggi keadilan. 